\begin{tabular}{|c|c|}
\hline $\begin{array}{l}\text { Univerzitet u Beogradu } \\
\text { Poljoprivredni fakultet } \\
\text { Institut za poljoprivrednu tehniku }\end{array}$ & $\begin{array}{r}\text { University of Belgrade } \\
\text { Faculty of Agriculture } \\
\text { Institute of Agricultural Engineering }\end{array}$ \\
\hline $\begin{array}{l}\text { Naučni časopis } \\
\text { POLJOPRIVREDNA TEHNIKA }\end{array}$ & $\begin{array}{r}\text { Scientific Journal } \\
\text { AGRICULTURAL ENGINEERING }\end{array}$ \\
\hline $\begin{array}{l}\text { Godina XLVI } \\
\text { Broj 1, } 2021 . \\
\text { Strane: } 54-62\end{array}$ & $\begin{array}{r}\text { Year XLVI } \\
\text { No. } 1,2021 \text {. } \\
\text { pp: } 54-62\end{array}$ \\
\hline
\end{tabular}

UDK: 631.373; 664.863; 63.558.1

\title{
THE MOBILE GRAPE TRELLISES
}

\author{
Alexander Kharibegashvili*1, ${ }^{1}$ Vladimer Miruashvili ${ }^{3}$, Svimoni Okhanashvili ${ }^{2}$, \\ Manana Kevlishvili ${ }^{2}$, Mzia Gagolishvili ${ }^{2}$, Levan Shavadze ${ }^{2}$ \\ ${ }^{1}$ Faculty of Exact and Natural Sciences, Iakob Gogebashvili Telavi State \\ University, Georgia \\ ${ }^{2}$ Faculty of Agrarian Sciences, Iakob Gogebashvili Telavi State University, Georgia \\ ${ }^{3}$ Department of Agricultural Engineering, Tbilisi Scientific Research Center of \\ Agriculture, Georgia
}

\begin{abstract}
The amount of the work in the vineyard, its yield greatly depends on what type of grape trellis is used in the vineyard.The most common is the Vertical Shoot Position.The advantages of the Vertical Shoot Position is the simplicity of the device and the use of inexpensive building materials. It is less time consuming and easily accessible for vineyard care.The disadvantages are that the maximum area of the green mass and the maximum yield cannot be obtained.The horizontal grape trellis system pergola - allows to get the maximum area of green mass, the maximum assimilation of solar energy takes place, that increase yields by 2-3 times and provide the best quality of grapes.The disadvantages is that the care of vines grown on horizontal trellis is very time-consuming. Because the vintner is forced to work with his head constantly pulled back and his arms raised high. The authors have developed a new type of grape trellis - a mobile pergola - which during the vegetation - during the development of green mass and fruit ripening are placed horizontally, and during the green operations - pruning, spraying, harvesting - in a vertical position. As a result, we get a high yield typical for the pergola, which is 2-3 times higher than the yield obtained on the vertical grape trellis, and its maintenance is just as convenient and simplified as that of the vertical grape trellis.
\end{abstract}

Key words: grape trellis system, vertical shoot positioning support system, mobile trellis, two plane vertical grape trellis, pergola, yields

\footnotetext{
*Corresponding Author. Email: telavi_inst@yahoo.com
} 


\section{INTRODUCTION}

In viticulture, as well as in all fields of agriculture, one of the main tasks is to increase productivity and product quality, reduce its cost, which depends on many factors, including the quality performance of vine care, vine formation, vine training green operations pruning; spraying, mechanical and chemical tillage, fertilizer, irrigation, grape variety, etc.

In all these directions, scientific-research works are being carried out to increase the quality of the grape and yields.

The laboriousness (labor intensity) of working in the vineyard, its yield also greatly depends on what type of grape trellis is used in the vineyard.

Grape trellis is characterized by a number of positive characteristics:

1. Grape trellises allow us to properly form the frame of a vine in the first years and then maintain its shape;

2. Distribute the vine buds evenly over the flatness of the trellis, so that all the leaves get as much sunlight as possible;

3. Convenient construction of trellises makes it easier for the viticulturist to take care of the vines and harvest;

4. At the expense of good lighting, raising the plane of leaves at a certain distance from the soil, good air circulation in the area where the leaves planes placed, decrease the probability of fungal diseases.

\section{MATERIAL AND METHODS}

Various grape trellises that exist today were taken as material. As methods studying these trellises, their pros and cons; analysis, creation - invention of a new type of grape trellis.

There are many ways to cultivate a vineyard in the world, many types of grape trellis have been developed.

The most common and widely used grape trellis is the Vertical Shoot Position Trellis (Негруль, 1952); (Смирнов К.В., et.al., 1987), also known as VSP invented by the famous Austrian viticulturist Lenz Moser in the 1930s (Fig. 1).

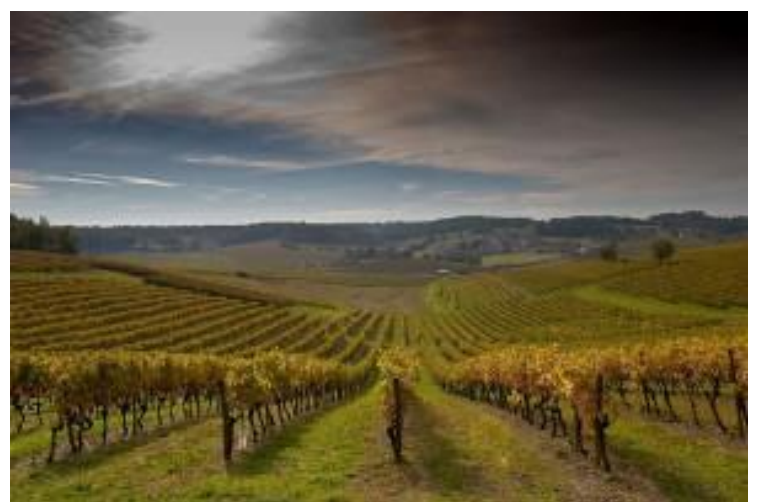

Fig. 1. VerticalShoot Position 
The disadvantages are that the maximum area of the green mass and the maximum energy assimilation of the sun's rays cannot be obtained, as a result, the maximum yield cannot be obtained.

The horizontal grape trellis system or pergola has been used by mankind since ancient times (Goldammer, 2018), (Klewir et.al., 2000), (Fig. 2).



Fig.2 Horizontal Trellis system the Pergola

This system of vineyard cultivation has a number of advantages. First of all, we get the maximum area of green mass, the energy is assimilated throughout the day and the vine gets the maximum energy of the sun. Grapes are protected from sunburn by leaves. Such farming techniques increase yields by 2-3 times and provide the best quality of grapes (Goldammer, 2018 ), (Reynolds, VandenHeuvel, 2009).

But the horizontal trellis system - the pergola - has a significant disadvantage, the care of vines grown on a horizontal trellis is very time-consuming (Girly, 2009). The vintner is forced to work with his head constantly pulled back and his arms raised high. Therefore, this method of vineyard cultivation is not often used in large areas, on an industrial scale (commercial grape growing). In such vineyards, the use of mechanization, the tractor is limited, cause the pergola in the vineyard cultivated on an industrial scale should be at human height.

It is more accepted as a decorative element of landscape design of private houses the pergola gives a special beauty and coziness to the gardens and yards of private houses. In the yard of private houses, a pergola is usually placed above to save space under the pergola (or alley) can be placed a table, chairs, or this space can be used for other useful purposes. When caring for a vine on such an alley, a ladder or its replacement device is used, which the viticulturist can not touch due to engaging in green hand operations while working, and there is a risk of its fall - trauma.

In viticulture also is used T-shaped pergola (trellis system): (Негруль, 1952); (Смирнов К.В., et.al., 1987); (Goldammer, 2018. ), consisting of a vertical pole and shoulders mounted horizontally on it (Fig.3) (T-shaped horizontal trellises). 


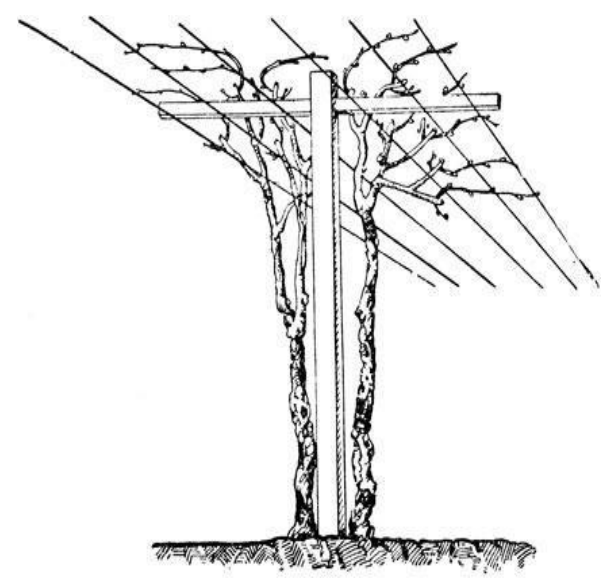

Fig.3. T-shaped pergola (trellis system)

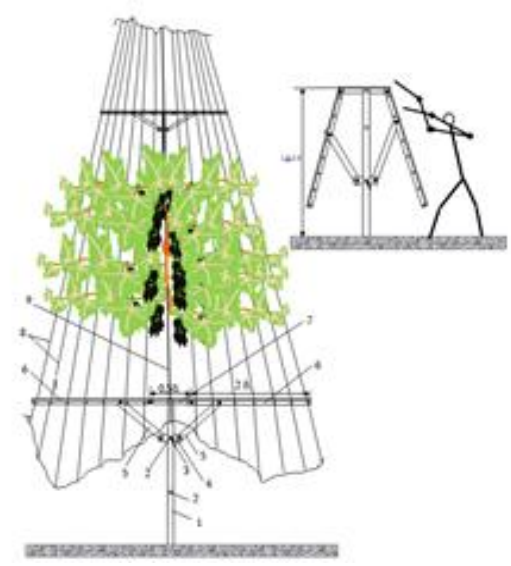

Fig.4. T-shaped Mobile Trellis

We propose a T-shaped trellis system - a mobile trellis (Kharibegashvili, et.al., 2020), the shoulders of which are movably attached to the poles by the hinges with the possibility of mounting them vertically and horizontally (Fig. 4). Only one-year-old branches take part in the bending, which are replaced with new ones every year (they have enough flexibility and elasticity to participate in bending-unfolding).

During the vegetation period - the development of green mass and fruit ripening the shoulders are placed horizontally, and during the green operations - during pruning, spraying, harvesting - in a vertical position. Figures 5, 6 show a technical drawings of the T-shape trellis system - a mobile trellis with folding shoulders (Fig. 5) and an axonometric view of two adjacent rows of the trellis (Fig. 6). Figs. 5, 6 show trellises with both folded and outstretched shoulders.

As a result of the stretching of hawser 13 (stretching can be done with a winch), the shoulders 5 are raised and placed horizontally in the whole row. When releasing the hawser13, the shoulders 5 gradually lower and stand upright.

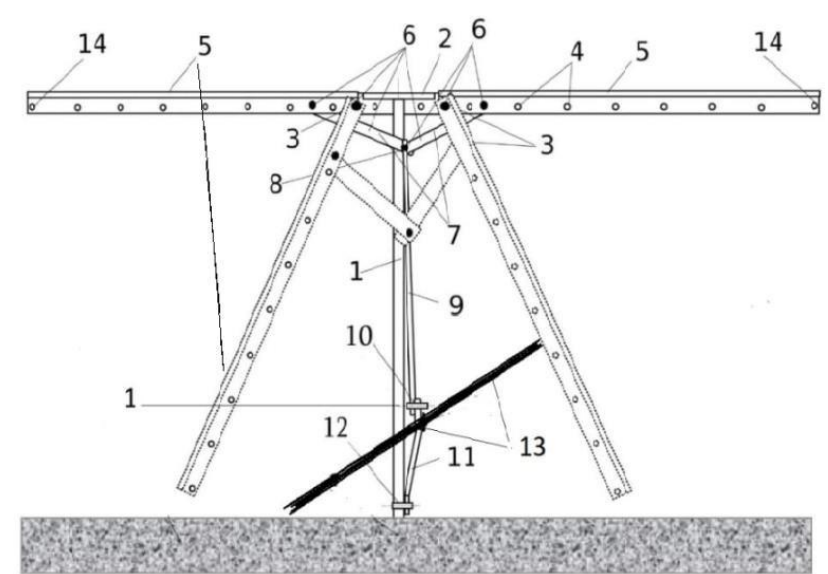

Fig.5. Technical drawing of the T-shaped Mobile Trellis 


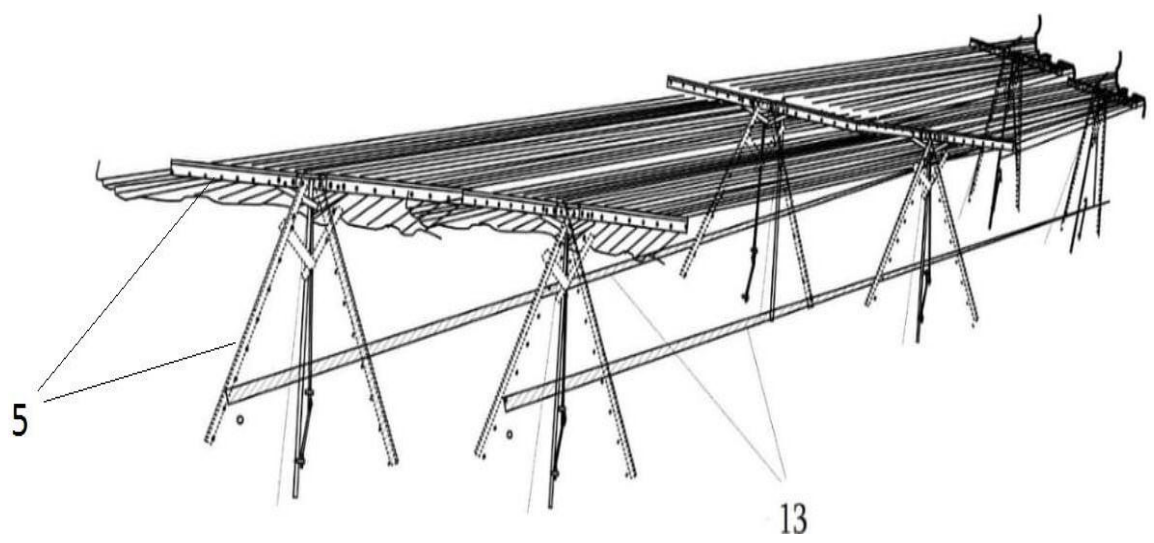

Fig.6. Axonometric views of two adjacent rows of the T-shaped Mobile Trerllis

Today (although less) also is used two plane vertical trellis (Fig. 7), which are two vertical rows located close to each other $(60-100 \mathrm{~cm})$ (Радчевский П.П., et.al., 2010). It is difficult to understand what the viticulturists are guided by when they install such trellis for grapes. When even the technical varieties of grapes grown on a single row vertical grape trellis - VSP (vertical shoot position system), if the summer does not turn out quite sunny, can not collect enough sugar. It is clear that the adjacent rows of these two plane trellis will overshadow each other and will not give us a large crop, while the sugar content of the grapes will not be high.

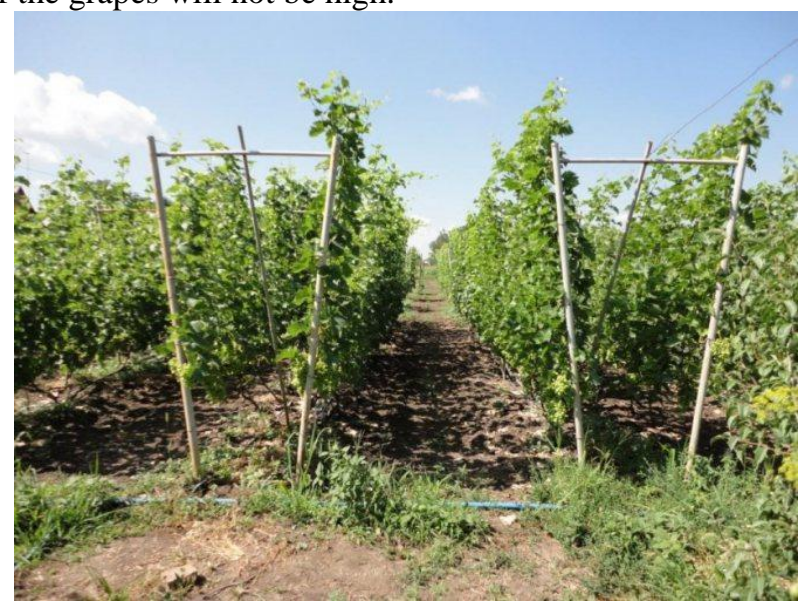

Fig.7. Two-plane trellis

But if the upper part of such trellis will be articulated (movably connected) to the lower part and we will provide them with a mechanism to change the position of the upper part of the trellis, then it will be possible to place the rows horizontally or close to the horizontal during vegetation. We get a two-plane mobile trellis (Fig. 8). 
For such Two plane mobile trellis, we have developed a simple mechanism for mounting the rows vertically and horizontally, which will allow the owners of such trellis to easily upgrade it.

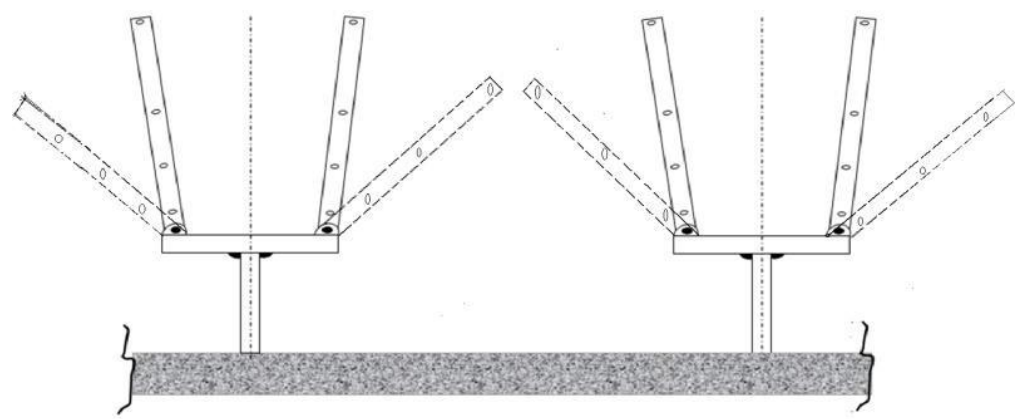

Fig. 8 Two-plane Mobile Trellis

We have also developed a T-shaped Balanced Mobile Trellis (Figure. 9), the upper part of which rotates around an axis located in its center. The symmetry of the weights of the trellis shoulders (more or less balanced of the torques) about the stake (pillar) - the axis is placed on it - does not require large loads from the service personnel when placing this trellis in a horizontal or vertical position.

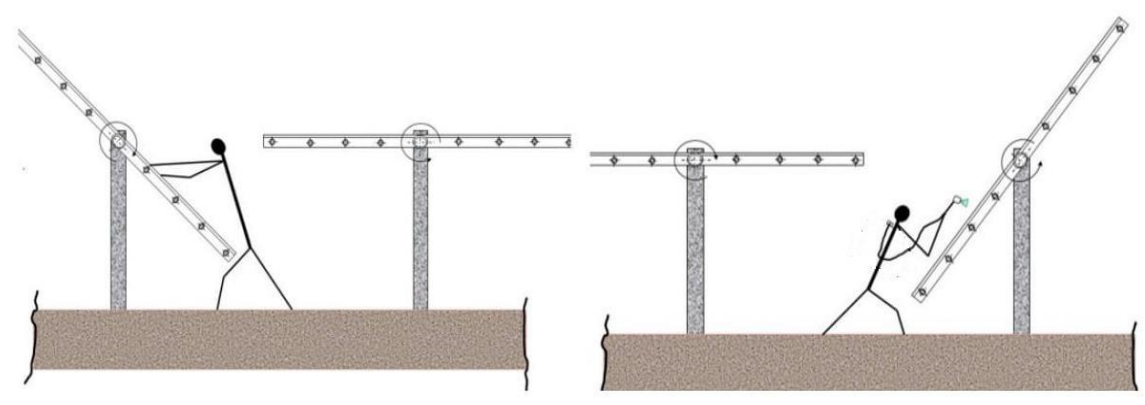

Fig. 9 Balanced T-shaped Mobile Trellis

\section{RESULTS}

The proposed types of grape trellis - mobile pergola trellises - allow us to combine the advantages of horizontal and vertical trellises - to obtain a high yield characteristic of the pergola, which is 2-3 times higher than of the vertical trellis, and its maintenance is as convenient and simple as for the vertical trellis. Vertical installation of the trellis allows the use of mechanization, the tractor. 
Raising the plane of leaves at a certain distance from the soil decrease the probability of fungal diseases. Reducing labor time reduces the cost of grapes.

We have submitted an application for the proposed grape trellis project to Sakpatenti, the State Patent Office of Georgia. It is recognized as an invention and published in the Official Bulletin of Industrial Property of SAKPATENTI, THE NATIONAL CENTER OF INTELLECTUAL PROPERTY OF GEORGIA [7].

\section{DISCUSSION}

The disadvantage of the presented mobile grape trellis is its cost, it will be 3-4 times more expensive than vertical grape trellises, and not much more expensive than a T-shaped trellis (immobile). But if we take into account that its yield is 2-3 times higher than the vertical grape trellis, in 2-3 years it will compensate the costs incurred on it, and then we will get a net profit.

\section{CONCLUSIONS}

Today the world is characterized by a sharp, rapid increase in population and urbanization, a reduction in areas suitable for agricultural land.

If we also take into account that the area suitable for viticulture is limited by agroclimatic conditions, it becomes especially important to develop viticulture in an intensive type - to increase the grape yield in the same area of the vineyard - i.e. without increasing the area of the vineyard. The presented project meets this requirement, it is an ecologically clean solution to the problem of increasing grape yield - not associated with environmental pollution by chemicals.

The modern level of development of technologies and technics freely allows to introduce and spread the proposed project of grape trellises - a Mobile Trellises.

\section{REFERENCES}

[1] Негруль, А.М.1952. Винаградство. Москва. Сельхозиздат, ст.1-427.

[2] Смирнов К.В., Калмыкова Т.И., Морозова Г.С. 1987. Виноградарство. Агропромиздат, ст. 1-367.Учебник для студентов высших учебных.

[3] Goldammer, T. 2018. Trellising Grapevines in Grape Growers Handbook. A GuideTo Viticulture for Wine Production., Publisher: ApexPublishers

[4] Kliewer M.W., Wolpert J. A. and Benz, M. 2000. Trellis and vine spasingeffects on growth, canopy microclimate, yield and fruit composition of cabernet sauvignon. ActaHortic. 526, pp. 21- 32,

[5] Reynolds A. G., VandenHeuvel J. E., 2009. Influence of Grapevine Training Systems on Vine Growth and Fruit Composition: A Review. American Journal of Enology and Viticulture 60(3), pp. 251-268.

[6] Girly M., 2009. The demise of the Italian pergola trellis. Australian Viticulture 37, September/October 2009, v13n5, pp. 37-38 
[7] Kharibegashvili A., Miruashvili V., Kevlishvili M., Shavadze L., Gagolishvili M., 2020, Grape Trellis Invention. Official Bulletin of Industry Property, SAKPATENTI, NATIONAL INTELLECTUAL PROPERTY CENTER OF GEOERGIA 09. 25.18 (550)

[8] Радчевский П.П., Матузок Н. В., Трошин Л. Н. 2010. Новации виноградартства Росии 19. Уход за молодыми насаждениями и установка шпалеры. Научныйжурнал КубГАУ, №57 (03).

\title{
POKRETNI NASLONI ZA VINOVU LOZU
}

\author{
Alexander Kharibegashvili ${ }^{1}$, Vladimer Miruashvili ${ }^{3}$, Svimoni Okhanashvili ${ }^{2}$, \\ Manana Kevlishvili ${ }^{2}$, Mzia Gagolishvili², Levan Shavadze ${ }^{2}$ \\ ${ }^{I}$ Faculty of Exact and Natural Sciences, Iakob Gogebashvili Telavi State \\ University, Georgia \\ ${ }^{2}$ Faculty of Agrarian Sciences, Iakob Gogebashvili Telavi State University, Georgia \\ ${ }^{3}$ Department of Agricultural Engineering, Tbilisi Scientific Research Center \\ of Agriculture, Georgia
}

Sažetak: Količina i obim rada u vinogradu, njegov prinos u velikoj meri zavisi od toga koja se vrsta naslona (rešetki) koristi u vinogradu. Najčešći je vertikalni položaj naslona rešetki. Prednosti vertikalnog položaja rešetki (naslona) za vinovu lozu je jednostavna konstrukcija kao i upotreba relativno jeftinog materijala za izradu.

Ali ovakav tip naslona ima manju dugotrajanost i ako je lako dostupan za postavljenje i negu vinograda.

Nedostaci ovakvih (vertikalnih) konstrukcija naslona su što se ne može dobiti maksimalna površina zelene mase i maksimalan prinos vinove loze.

Horizontalni sistem naslona (pergola) za vinovu lozu omogućava da se dobije maksimalna površina zelene mase, dobija se maksimalna asimilacija zbog izloženosti suncu, što povećava prinose za 2-3 puta i obezbeđuje najbolji kvalitet grožđa.

Nedostaci ovog načina je briga o vinovoj lozi podignutoj na horizontalnim naslonima postoje, jer vinogradar je primoran da radi u pojedinim opracijama nege vinograda sa neprestano pognutom glavom i visoko podignutim rukama (zbog ograničene visine horizontalnih naslona ).

Autori ovog rada su razvili novu tip naslona za vinovu lozu i grožđe, pokretnu pergolu, koja se tokom vegetacije i razvoja zelene mase i sazrevanja grožđa postavlja u horizontalni položaj. U toku zelenih operacija orezivanja, zaštite vinove loze, a zatim berbe grožđa, naslon (rešetka) se nalazi u vertikalnom položaju, kada je bolji pristup svim operacijam nege vinograda.

Kao rezultat, dobijen je visok prinos tipičan za pergolu, koji je 2-3 puta veći od prinosa dobijenog na isključivo vertikalnim naslonima (rešetkama) za vinovu lozu, dok je održavanje ovog tipa naslona jednako prikladno i pojednostavljeno kao i kod vertikalnih naslona za grožđa. 
Ključne reči: Rešetkasti sistem naslona grožđa, vertikalni sistem podrške za pozicioniranje izdanaka, pokretni nasloni za grožđe, pergola, prinosi

Prijavljen:

Submitted: 21.01.2021.

Ispravljen:

Revised: $\quad 02.02 .2021$.

Prihvaćen:

Accepted: 03.03.2021. 